\title{
Determinants of Banking Efficiency and its Impact on Banking Competitive Advantage
}

\section{Andi Ruslan', Cepi Pahlevi², Syamsu Alam ${ }^{3}$ and Mursalim Nohong ${ }^{4}$}

\author{
${ }^{1}$ Institut Agama Islam Negeri (IAIN) Bone, Indonesia, e-mail: oland3aa@gmail.com \\ ${ }^{2}$ Hasanuddin University, Indonesia \\ ${ }^{3}$ Hasanuddin University, Indonesia \\ ${ }^{4}$ Hasanuddin University, Indonesia
}

\begin{abstract}
This paper aims to identify the level of competition and the level of banking efficiency and develop a conceptual framework to examine the effect of the level of banking competition, the characteristics of banks on efficiency and competitive advantage of banking. To discuss the topic studied in this paper, the Literature Review method is used. The steps in creating a literature review are described as follows: First, determine the sources for the review literature material that is in accordance with the topic of this paper. Secondly, evaluating the contents contained in the sources of the literature study that was determined. Third, make a summary of the contents of the literature study resources. And fourth, explore new thoughts and ideas on topics that are subject to study to determine the positioning of the concept as the material for subsequent research. This finding shows that the level of competition, characteristics of banks influence in increasing competitive advantage through efficiency in the banking sector.
\end{abstract}

Keywords: Bank Competition, Bank Characteristic, Bank Efficiency, competitive advantage

\section{Introduction}

In Indonesia, the banking industry experienced structural developments and changes since the introduction of the deregulation package in October 1988 by the government. Through this policy, the government provided the liberalization or concession permits for bank establishment. As a consequence, the number of banks in Indonesia experienced a significant increase to 111 banks in 1988 and reached a peak of 240 banks in 1994 (Enoch et al, 2001). Structural changes occurred again due to the 1997 economic crisis. The number of banks in Indonesia decreased due to a merger of state banks and liquidation of 23 banks. Furthermore, through the Indonesian Banking Architecture (API) which was introduced in 2004, Bank of Indonesia as a banking authority revert to encourage the consist of a healthy banking market structure, among other the process of merger and consolidation. At present, the number of commercial banks in Indonesia reaches 120 banks (Hafidz \& Astuti 2013) The development of banking industry today can be seen from the growth of banking business activities from year to year. Based on data from the Financial Services Authority (FSA) it can be seen that the banking activities in Indonesia relating to fund distribution activities, experienced a rapid development from 2013 amounting from to Rp. 4,823 to 7,177 trillion for commercial banks in 2017. Furthermore, the channeling of BPR funds in 2013 amounted to Rp. 74 trillion to Rp. 121 Trillion in 2017, an increase in the number of activities also occurred in the source of banking funds in 2013 which amounted to Rp. 4,070 Trillion for commercial banks to Rp. 5,921 trillion in 2017, while for BPRs Rp. 64 trillion in 2013 to Rp. 103 trillion in 2017. Other indicators such as the number of assets and the number of offices both commercial banks and rural banks continue to increase.

The developments show that the banking industry still plays the biggest role in the Indonesian's financial system with a share of around $75 \%$ by the end of 2012 . Therefore, the banking sector must be able to operate efficiently, soundly and stably to encourage sustainable and more equitable economic growth through easy, safe, and affordable financing. The efficiency aspect is one of the important factors that need to be considered because it can affect the business continuity of the bank. In addition, the increase of bank efficiency is expected to lower the credit interest rates of banking that the efficiency has an effect. Not only on the bank, but also on the community (Hafidz \& Astuti 
2013) and if there is a rapid change in financial structure, then it is important to identify the efficiency of costs and income. The more efficient bank is expected to get optimal benefits, more loan funds, and better service quality to customers. (Berger, et al. 1993).

However, the level of banking efficiency in Indonesia is still considered low or even inefficient. This can be seen from several studies which show that the level of banking efficiency in Indonesia is still low. The study carried out by Muazaroh et al (2012) using the Stochastic Frontier Analysis to find that bank efficiency scores in Indonesia are still inefficient. Another, the research conducted by Yusniar (2011) using the Stochastic Frontier Analysis and Analysis Data Development showed that the level of banking efficiency in Indonesia experienced an increase but was relatively low.

The level of bank efficiency is influenced by quite a number of factors, both internal (including activities, characteristics and business activities of the bank) and external (including levels of competition and economic conditions). Competition conditions can be seen through the level of rivalry in an industry. But amidst the rapid development of the banking sector the level of competition in the banking industry in Indonesia is still considered low. According to several studies, it is because of the market structure in the banking industry in Indonesia which is still monopolistic. Several studies have been conducted to find out the level of banking competition in Indonesia, one of which is Claessen and Laeven (2004) that estimate the level of competition in 50 countries including Indonesia using the Panzar-Rosse method in the period 1994-001. From the study, it is stated that the structure of the Indonesian banking industry belongs to the category of monopolistic competition. This illustrates that the level of banking competition in Indonesia is still low. While competition is the main foundation of the process of strengthening national banks so that changes in the level of competition between banks will also change the behavior of banks in managing their businesses that encourage banks to be more efficient and have competitiveness. Several studies have shown that competition between banks can influence the bank performance, one of which has a positive impact on efficiency (Casu and Girardone, 2007, Schaeck and Čihák, 2008). Other studies related to the effect of the level of competition on bank efficiency carried out by (Arrawatia et al, 2016) found that competition has a positive effect on banking efficiency.

Other factors that influence bank efficiency are internal factors of the bank itself, namely the characteristics of the bank. Bank characteristics can consist of bank size, bank type and bank capital. Research related to this was done by Muazaroh et al (2012) found that bank size, capital, type or structure of bank ownership has a positive effect on bank efficiency. Research conducted by Yusniar (2011) also found that bank characteristics such as bank size and capital affect bank efficiency.

The achievement of maximum efficiency will make banks have a competitive advantage in the industry. In achieving competitive advantage of an organization there are two commonly used approaches the first one is outside-in approach developed by Porter (1980) which is known as a market or industry-based approach. This approach emphasizes that external market forces such as demand uncertainty, technological turbulence, and competitive intensity drive competitive advantage. The second approach is the inside-out where this approach maps the resources they have and then determines what industries and strategies are chosen. This approach was developed by Barney (1991), emphasizing that the competitive advantage of a company is determined by the characteristics that exist within the company itself. One of them is tangible resources which are assets that can be seen and calculated. The resources are easily identified and evaluated. The resources are financial resources, organizational resources, physical resources and technological resources. This approach requires the existence of value, scarcity, inimitable and organized to gain excellent and sustainable performance. Furthermore, Kasasbeh et al (2017) Identifying one of the important antecedents for conceptualizing and investigating the construction associated with competitive advantage in the banking sector is efficiency. Thus, it is necessary to develop a conceptual framework for the relationship between efficiency and competitive advantage in the banking sector. 
This paper aims to identify the level of competition and the banking efficiency and to analyze the influence of the level of competition, bank characteristics towards efficiency and competitive advantage in the banking sector.

Competition is overcoming and fighting between two individuals or groups to fight for the same object (Chaplin, 1999). Competition is often associated with market power (market power) even though these two things are actually different. Market power refers to the behavior of individual companies in managing price strategies, while competition is more related to the interaction of market members or more aggregate (de Rozas, 2007).

With regard to competition, there are two types of markets, the perfect competition markets and imperfect competition markets. The market of perfect competition has the characteristics of many sellers and buyers, and also prices are determined by market forces. The prevailing conditions in this market are free market participants to exit or to enter the market, homogeneous types of goods, as well as no transaction fees or transportation costs. Meanwhile, the imperfect competition market is all types of market that are opposite to perfect competition, specifically monopoly and monopsonies, oligopoly, and monopolistic competition (Hafidz \& Astuti 2013)

In the banking industry, calculating the level of competition is important. Interbank competition can occur due to the struggle of productive resources, for example deposits, savings, and credit distribution which are sources of income. Nonbank interbank competition can take the form of prizes or promotions aimed at reaching as many customers as possible. In addition, competition can also take the form of new products and types of services supported by technological developments that can reduce production and distribution costs. The characteristics of banks that are different from nonbank companies in general, as well as the important role of banks in the economy, cause a lot of research on the level of competition carried out using banking data.

There are two approaches used to analyze the level of competition, structural and nonstructural approaches. In the structural approach, the Herfindahl-Hirschman Index (HHI) method is used to analyze the concentration level of bank business by using the share of each bank. The high HHI index indicates low competition. In the nonstructural approach two methods will be used, Panzar - Rosse and Indicator Boone. The Panzar - Rosse is used to analyze the structure of banking competition using the intermediation approach. In this case, the changes in bank input prices (labor, physical capital, and interest expenses) will affect the bank's (interest) revenue. The market is monopolistic (has a low competition) when the Panzar Rosse index is 0 (zero). The Boone indicator is used to calculate the competition index which is the result of the estimation of the relationship between relative market shares (MS) and relative marginal cost (MC). Market share shows competition and marginal cost are a proxy of efficiency. This indicator shows that the high marginal cost causes competition to increase. (Hafidz \& Astuti 2013)

The level of competition can also be measured using the Lerner Index (L). This index measures the level of monopoly power possessed by a company. The unit is $\mathrm{L}$ which is the ratio between price difference $(\mathrm{P})$ and marginal cost $(\mathrm{MC})$ to price, or the bias is also divided by the absolute number / value of the elasticity of the demand price (e). L values can range from zero (for perfectly competitive companies) to one (for monopolists). (Salvatore, 2006)

Research on the influence of banking competition on efficiency (Arrawatia et al, 2016) found that competition has a positive effect on banking efficiency, (Casu \& Girardone, 2007) finding competition capable of stimulating banks to be more efficient, while research (Titko J, et all, 2014) shows a strong negative relationship between competition and efficiency in banking.

One of the important questions related to the banking consolidation policy is whether the size of the bank affects efficiency. If large banks are more efficient than small banks, then banks in Indonesia enjoy increasing scale. Based on the literature on economies of scale, the size of a bank will have a positive effect on the efficiency of a bank but for a very large bank, the effect of the size of the negative bias. Therefore, the effect size on efficiency may not be linear. Research on the effect of bank size on efficiency finds inconsistent results. Kwan and Eisenbeis (1997) found negative results, 
while other studies found positive results (Berger, et al., 1993). Other research results (Cebenoyan, et al., 1993); (Mester, 1996)) found no significant results.

Other research (Hasanul Banna et al, 2017) found that bank size has a positive and significant effect, (Muazaroh et all, 2012) found positive and significant results, (Yusniar, 2011) found positive and significant results, (Perwitaningtyas \& Pangestuti, 2015) found positive and significant results, while other studies (Claudia Girardone et al, 2004) found that there was no clear relationship between bank size and bank efficiency.

The type of bank ownership also affects the level of banking efficiency. Foreign banks have expertise in risk management, corporate governance, technological innovation, and better operational strategy techniques (Perwitaningtyas \& Pangestuti, 2015). Research on the effect of bank ownership types on efficiency (Muazaroh, et al., 2012) found that foreign banks were more efficient than domestic banks, (Sturm and Williams, 2004) found that in Australia foreign banks were more efficient than domestic banks because of their superiority in scale. efficiency. (Perwitaningtyas \& Pangestuti, 2015) found that the type of bank ownership affects efficiency where foreign banks are more efficient than domestic banks, this is because foreign banks and domestic banks have different operational strategies and corporate culture in terms of achieving maximum efficiency. While studies empirically conducted by Berger found that domestic banks were more efficient than foreign banks (Berger and Humphrey, 1997). This result shows the difference in the relationship between bank ownership type and efficiency.

Capital aspects of a bank can be measured using the Capital Adequacy Ratio (CAR). CAR is the bank's capital adequacy ratio or is the ability of banks in existing capital to cover possible losses in credit or in the trading of securities. CAR is also considered as one of the factors that can affect the level of bank efficiency. CAR can reflect the ability of a bank to face the possibility of an unexpected loss risk because the level of CAR held by a bank can shape market perceptions of the security level of the bank concerned. With an adequate CAR or fulfill the requirements, the bank can operate properly, so that it will generate profits. In other words, the higher the CAR the better the performance of a bank. Optimal credit distribution assuming there is no bad credit will increase profits which will ultimately increase the efficiency of the bank (Yusniar, 2011) Capital Adequacy Ratio (CAR) shows the capital adequacy of the total assets owned by the bank. CAR is also considered as one of the factors that can affect the level of bank efficiency. The higher the CAR the better the performance of a bank. Optimal credit distribution assuming there is no bad credit will increase profits which in turn will increase the efficiency of the bank. (Muazaroh et al, 2012)

Research on the influence of capital on efficiency (Muazaroh et al, 2012) found that capital has a positive and significant impact on efficiency, (Yusniar, 2011) that CAR plays a positive and significant impact on efficiency, (Hasanul Banna, 2017) found positive results and significantly, (Claudia Girardone et all, 2004) found positive and significant results, whereas (Perwitaningtyas \& Pangestuti \& Irene, 2015 found that CAR has a negative influence on efficiency.

Banking as a financial intermediary (financial intermediary) between parties that have funds and parties that need funds, has a strategic role in the economic growth of a country. Increased efficiency in the banking sector will encourage greater mobilization of savings and deposit funds and loan demand, thereby increasing economic growth (Karimzadeh, 2012). Efficiency can be divided into three types, namely: (1) Technical Efficiency, efficient if a company refers to maximizing output with a number of inputs. (2) Allocative Efficiency, concerning the selection between a combination of the use of technically efficient inputs to produce the maximum possible output. (3) Cost efficiency or Economic Efficiency is a combination of technical efficiency and allocative efficiency. If the organization uses it completely between technical efficiency and allocative efficiency efficiently it can be said to have achieved total economic efficiency (Worthington, 2004).

Bank efficiency is one indicator of bank performance. Bank efficiency is an indicator in measuring the overall performance of bank activities. Efficiency is often defined as the organization's ability to produce maximum output using a certain level of input or use the minimum input to the level of 
output. Efficiency and effective utilization of resources is the key to the success of a bank. Several recent developments and events in the banking industry have a greater emphasis on banking efficiency. Various changes in the banking sector in Indonesia such as bank restructuring, privatization and bank prudential policies have been carried out to improve the banking sector. This change is expected to encourage the creation of efficiency in the banking sector. The creation of banking efficiency is expected to encourage the banking system to be resistant to shocks and competition and ultimately promote financial system stability. (Muazaroh et al, 2012)

In analyzing efficiency can be used two methods, namely Stochastic Frontier Analysis and Data Envelopment Analysis. Stochastic Frontier Analysis (SFA) is used to analyze the level of bank efficiency obtained through the intercept of the relationship between the factors of cost, profit or production on input, output, and environmental factors. The high intercept shows conditions that are not more efficient when compared to a lower intercept. Data Envelopment Analysis (DEA) is a nonparametric approach to finding efficiency frontiers based on optimum input-output combinations. (Hafidz \& Astuti 2013)

Companies are said to have competitive advantages over other companies, if the company has greater profitability than the average profitability of competitors in an industry. While the company is said to have sustainable competitive advantage if the company is able to maintain its profitability above the industry average profitability for years (Porter, 1998). Furthermore, according to Porter (1998), the company's competitive advantage comes from two things, namely: cost leadership and differentiation. The company will be in a cost leadership situation if the company has the lowest cost to produce and market goods or services compared to other companies in the same industry.

In achieving competitive advantage of an organization there are two commonly used approaches namely the first outside-in approach developed by Porter (1980) which is known as a market or industry-based approach. This approach emphasizes that external market forces such as demand uncertainty, technological turbulence, and competitive intensity drive competitive advantage. The two approaches from inside-out where this approach maps the resources they have and then determines what industries and strategies are chosen. This approach was developed by Barney (1991) which requires the existence of value, scarcity, cannot be imitated and organized to obtain sustainable excellence and performance.

The debate often occurs between the Outside-in approach or commonly referred to as an industrial organization perspective with an inside-out or resource-based view approach. This debate occurs because each approach departs from a different perspective. Industrial organization assumes that competitive advantage is determined by the company's external factors namely attractive industries. However, the industrial organization perspective is unable to explain why many companies have different performance. Resource-based view perspective answers this phenomenon, that each company has different resources so that the resulting performance is also different. So, resourced based views assume that the source competitive advantage comes from the company's internal.

\section{Research Methodology}

To discuss the topic studied in this paper, the Literature Review Method is used. This Literature Review is intended to solve a problem that basically relies on a critical and in-depth review of relevant library materials. Literature review is done by collecting data or information from various sources of literature needed as a source of ideas to explore new thoughts or ideas, as a basis for deduction from existing knowledge, so that a new theoretical framework can be developed, or as a basis for problem solving. The literature review approach consists of 5 stages; 1) Find models, 2) Problem formulation - which topics are under consideration and what are constituent issues, 3) Literature search, 4) Evaluation of findings, and 5) Analysis and the interpretation of literature. (Handrimurtjahjo, 2012). Library sources reviewed in this paper are: books, research results, journals, and other scientific articles. The steps in creating a literature review are described as follows. First, determine the resources for literature review material that is in accordance with the topic of this paper. Secondly, 
evaluate the contents contained in the sources of the literature study that was determined. This section includes points relating to basic assumptions or facts that are considered correct without verification and limitations, namely certain aspects that are used as a framework for thinking. This analysis is needed to develop the flow of thinking in solving problems. Third, make a summary of the contents of the literature studied. And fourth, explore new thoughts and ideas on topics that are subject to study to establish concept positioning as the material for subsequent research.

\section{Result and Discussion}

The efficiency and effective utilization of resources are the keys to success of a bank. Some recent developments and events in the banking industry have a greater pressure on banking efficiency. Various changes in the banking sector in Indonesia such as bank restructuring, privatization and bank prudential policies have been carried out to improve the banking sector. This change is expected to encourage the creation of efficiency in the banking sector. The banking efficiency is expected to encourage the banking system withstand the blows and the competition competition and eventually stimulate the financial system stability (Muazaroh et al, 2012)

The level of efficiency achieved reflects good quality performance. The level of bank efficiency is influenced by quite a number of factors, both internal (including activities, characteristics and business activities of the bank) and external (including levels of competition and economic conditions). The level of competition is considered as a positive factor in influencing bank efficiency, productivity, and innovation. In addition, competition is also considered as a driving factor in the consolidation process carried out by banks even though it can have an impact on increasing banking concentration so that the issue of the impact of competition on bank efficiency and performance continues (Amel et al, 2004). Bank characteristics are internal factors that affect the efficiency of a bank. Bank characteristics consist of bank size, capital, type of bank ownership structure. Research related to this was carried out by Muazaroh et al (2012). This study examined the determinants of bank profit efficiency during the period 2005-2009 in Indonesian banks. In particular, checking bank size, credit risk, capital, ownership structure and market share on bank profit efficiency by using Stochastic Frontier Analysis (SFA) is to measure efficiency, then the obtained score related to a series of bank efficiency determinants are analyzed using regression techniques. This study showed that bank efficiency scores in Indonesia were still inefficient, furthermore the Bank Size, capital, bank ownership structure and market share had a significant impact on bank profit efficiency while credit risk had an insignificant effect on bank profit efficiency.

Research conducted by Banna et al (2017) to examine the effect of the global financial crisis and other factors on the efficiency of Bangladesh commercial banks used Data Envelopment Analysis (DEA) to see the level of efficiency then use regression techniques were used to see the effect of the global financial crisis and other factors in bank efficiency. The Empirical findings indicate that the Bangladesh banking sector shown the highest efficiency level during 2001, while efficiency seemed to be at its lowest point during 2010. The study also found that the joint crisis with bank size, capital adequacy ratio, average return on equity and interest rate real has a significant effect on bank efficiency in Bangladesh.

With maximum efficiency achieved, the bank will have a competitive advantage in the industry. According to Porter (1998), the company's competitive advantage comes from two things: cost leadership and differentiation. The company will be in a cost leadership situation if the company has the lowest cost to produce and market goods or services compared to other companies in the same industry.

In achieving competitive advantage of an organization there are two commonly used approaches namely the first outside-in approach developed by Porter (1980) which is known as a market or industry-based approach. This approach emphasizes that external market forces such as the of demand uncertainty, technological turbulence, and competitive intensity lead to competitive advantage. The second approach is the inside-out where this approach maps the resources they have and then 
determines what industries and strategies. This approach was developed by Barney (1991) emphasizing that the competitive advantage of a company is determined by the characteristics that exist within the company itself. They consist of 1 . Intangible resources which are assets that can be seen and calculated. This resource is easily identified and evaluated. These resources are financial resources, organizational resources, physical resources and technological resources; 2. Intangible resources are assets that can be felt but not tangible, such as human resources, innovation and reputation; 3. Organizational capability includes the capacity of companies to manage company resources in an integrated manner by using organizational processes to achieve the expected results. The results of a study conducted by Kasasbeh et al (2017) where the study examines the factors that influence competitive advantage in the banking sector by using systematic literature review. This study conceptualizes an organization's competitive advantage often determined by the nature of the organization being investigated. In financial institutions or banking studies that measure competitive advantage using financial and non-financial measures, financial measures are defined as the company's annual turn-out profits, measured by Return of Equity (ROE) or / and Return on Assets (ROA). In this study, competitive advantage was investigated as a dependent variable. From the perspective of non-financial measures, competitive advantage is defined as innovative ideas and the process of developing creative products from the organization. This is also defined as the development of services and increased sales and the growth of service quality, responsiveness to customers, the organization's core competencies and cost effectiveness.

Kasasbeh et al (2017) Identifying one of the important antecedents for conceptualization and investigating construction related to competitive advantage in the banking sector is efficiency. From the results of the above studies, a conceptual framework can be developed regarding the determinants of banking efficiency and its impact on competitive advantage in the banking sector as shown in Figure 1.

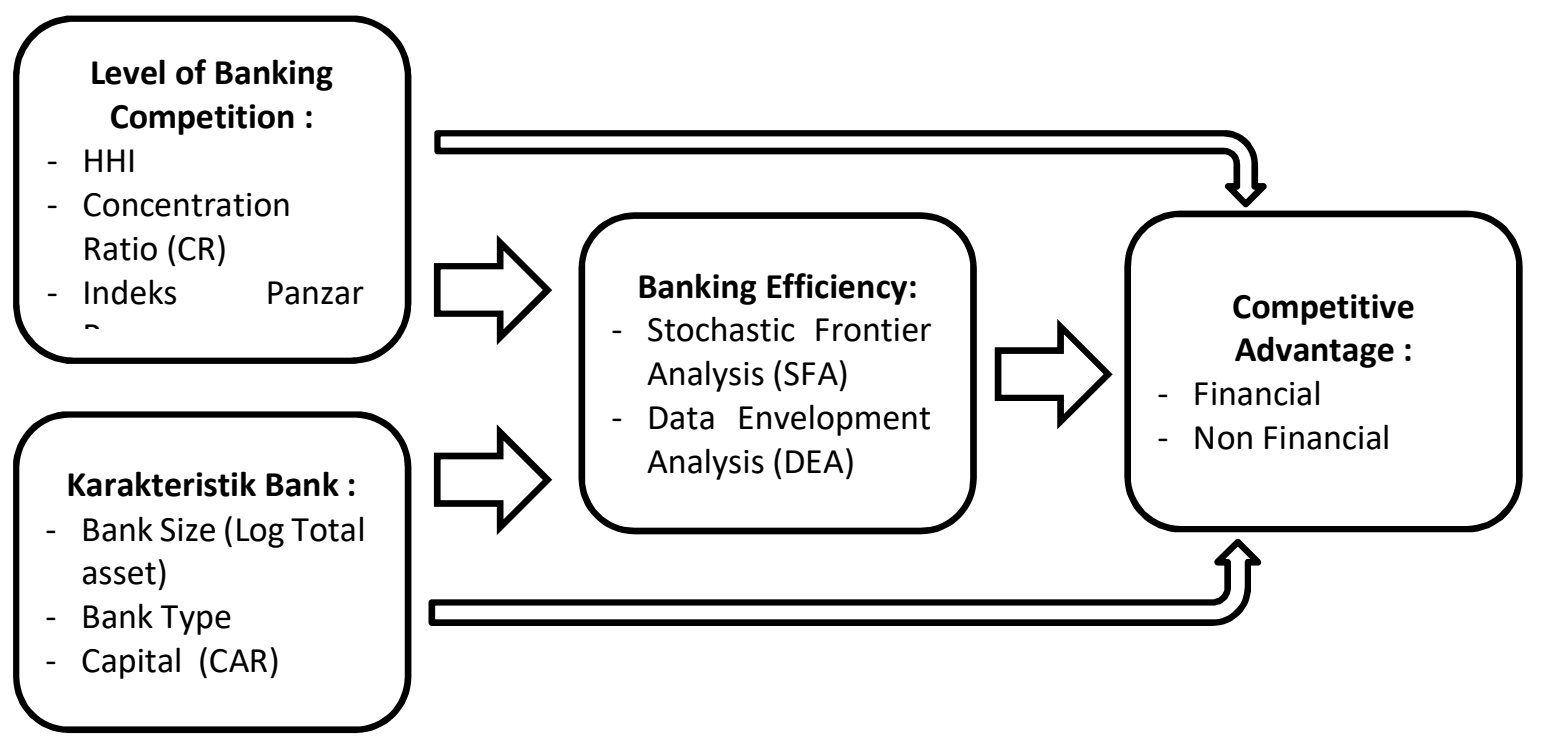

Figure 1. Conceptual Model of Efficiency and Competitive Advantage of the Banking Sector

\section{Conclusion}

This paper discusses the development of a conceptual framework to show the influence of the level of competition and the characteristics of bank in improving the efficiency and competitive advantage of the banking sector. The level of competition, the characteristics of bank are likely to have an effect the increase of banking efficiency and able to increase the banking sector's competitive advantage. This paper needs to be followed up by conducting empirical research and testing the model that was proposed in order to find the expected results. 


\section{References}

Amel, D, Barnes ,C, Panetta ,F \& Salleo, C, 2004, 'Consolidation and efficiency in the financial sector: A review of the international evidence'. Journal of Banking \& Finance, 28 2493-2519

Arrawatia, R, Misra, A, Dawar,V, 2016, 'Bank Competition And Efficiency: Empirical Evidence From Indian Market', International Journal of Law and Management. Emerald Insight, Vol. 57 Iss 3 pp. $217-231$

Banna, H, Ahmad, R \& Koh, H.Y.E, 2017, 'Determinants of Commercial Banks' Efficiency in Bangladesh: Does Crisis Matter?', Journal of Asian Finance, Economics and Business, Vol 4 No 3, 19-26

Barney J, Wright, M, Ketchen, D, 2001,'The resource-based view of the firm: Ten years after 1991'Journal of Management 27 (2001) 625-641

Berger, A.N. and Humphrey, D.B., 1997, "Efficiency of financial institutions: International survey and directions for future research". European Journal of Operational Research, 98 (2):175212.

Berger, A.N., Hancock, D. and Humphrey, D.B., 1993. 'Bank Efficiency Derived from the Profit Function'. Journal of Banking and Finance, 17 (2):317- 347.

Casu, B., dan C. Girardone. 2007. 'Does Competition Lead to Efficiency? The Case of EU Commercial Banks', Essex University, Discussion Paper No. 07-01

Cebenoyan, A.S., Cooperman, C.A. and Hudgins, S.C., 1993, 'The relative efficiency of stock vs mutual S\&Ls: A stochastic frontier approach'. Journal of Financial Services Research, 7:151170

Claessens, S and Leaven, L, 2004, 'What Drives Bank Competition?', Some International Evidence, Policy Research Working Paper, 3113 pp 1-33

Enoch, C., B. Baldwin, O. Frécaut, dan A. Kovanen. 2001. 'Indonesia: Anatomy of a Banking Crisis Two Years of Living Dangerously 1997-99', IMF Working Paper 01/52. Washington: International Monetary Fund.

Girardone, C, Molyneux, P, \& Gardener, E, 2004, 'Analysing the Determinants of Bank Efficiency: The Case of Italian Banks', Applied Economics, Vol. 36, No. 3, pp. 215-227

Hafidz, J \& Astuti, R. I, 2013, 'Tingkat Persaingan Dan Efisiensi Intermediasi Perbankan Indonesia', Working Paper Bank Indonesia, 1-49

Handrimurtjahjo, A. D, Kuncoro, E. A, 2012, 'Peran Daya Saing Kultural dan Kapabilitas Dinamik Dalam Meningkatkan Kinerja Organisasional', Binus Business Review Vol. 3 No. 2 November : 777-786

Karimzadeh, M, 2012. 'Efficiency Analysis by Using Data Envelop Analysis Model: Evidence from Indian Banks'. International Journal of Latest Trends in Finance \& Economic Sciences , 2 (3), $228-237$.

Kasasbeh, E. A, Harada, Y \& Noor, I, 2017, 'Factors Influencing Competitive Advantage in Banking Sector: A Systematic Literature Review', Research Journal of Business Management 11 (2) pp 67-73

Kwan, S. and Eisenbeis, R.A, 1997. 'Bank risk, capitalization, and operating efficiency'. Journal of Financial Services Research, 12 (2):117-131.

Mester, L.J., 1996, 'A Study Of Bank Efficiency Taking Into Account Risk Preferences'. Journal of Banking \& Finance, 20 (6):1025-1045.

Muazaroh, Eduardus, T, Husnan, S \& Hanafi, M, 2012, 'Determinants of Bank Profit Efficiency: Evidence from Indonesia', International Journal of Economics and Finance Studies Vol 4, no 2, pp 163-173

Pamulu, M.S, 2014, 'Membangun Keunggulan Bersaing Untuk Perusahaan Konstruksi, Suatu Pendekatan Sumberdaya dan Kapabilitas', Kementerian Pekerjaan Umum, https://www.researchgate.net/publication. 
Perwitaningtyas, G. A, Pangestuti, I. R, 2015, 'Faktor-Faktor yang Mempengaruhi Efisiensi Bank di Indonesia Periode Tahun 2008-2012', Diponegoro Journal Of Management Volume 4, Nomor 1 hh. 1-14

Porter, Michael E, 1998, 'Competitive Advantage : Creating and Sustaining Superior Performance', The free Press

Salvatore, D. 2006. 'Mikro Ekonomi', Edisi Ke Empat, Penerbit Erlangga, Jakarta

Schaeck, K., dan M. Čihák. 2008. 'How Does Competition Affect Efficiency and Soundness in Banking? New Empirical Evidence', ECB Working Paper No. 932. Frankfrurt: European Central Bank.

Sturm, J, Williams, B, 2004, 'Foreign Bank Entry, Deregulation and Bank Efficiency': Lessons from the Australian Experience, Journal of Banking \& Finance 28, El Sevier, 1775 - 1799

Titko, J, Lace, N \& Tleuzhanova, M, 2014, 'Competition and Efficiency in the Banking Sector of EU New Member States', Researchgate Publication.

Widyastuti, Ratna Sri \& Armanto, B. 2013. 'Kompetisi Industri Perbankan Indonesia'. Buletin Ekonomi Moneter Dan Perbankan, April 2013

Worthington, A. C. 2004. Frontier Efficiency Measurement in Health: A Review of Empirical Techniques and Selected Applicants. Medical Research and Review, Vol. 61, No. 2, hal. 1 36.

Yusniar, M.W, 2011, 'Analisis Efisiensi Industri Perbankan Di Indonesia Dengan Pendekatan Data Envelopment Analysis (Dea) Dan Faktor-Faktor Yang Mempengaruhinya', JURNAl MANAJEMEN \& BISNIS, Vol. 1 No.2 Maret, hh.175-195 